\title{
Kuminaöljyn tehokkuus puutavaran suojauksessa
}

\author{
Leena Paajanen ${ }^{1}$, Leila Vanhatalo ${ }^{1}$ ja Marjo Keskitalo ${ }^{2}$ \\ ${ }^{1}$ VTT Rakennus- ja yhdyskuntatekniikka,PL 1806,02044VTT, leena.paajanen@vtt.fi \\ ${ }^{2}$ Maa-ja elintarvikkeiden tutkimuskeskus, Kasvinviljely ja biotekniikka, 31600 Jokioinen, \\ marjo.keskitalo@mtt.fi
}

\begin{abstract}
Johdanto
Puutavaran suojaukseen etsitään jatkuvasti uusia ympäristölle vähemmän haitallisia vaihtoehtoja. Tutkimuksen tarkoituksena oli selvittää, voidaanko haihtuvia terpeeniyhdisteitä sisältävää, biologisesti aktiiviseksi todettua kuminaöljyjä $(1,2)$ käyttää puutavaran suojaukseen, sen homehtumisen, sinistymisen ja lahoamisen estoon, tai voidaanko sillä estää maalien homehtuminen puupinnoilla.
\end{abstract}

\section{Aineisto ja menetelmät}

Tutkittavat kuminaöljyt olivat projektia varten eristettyjä. Työssä käytettiin sekä puristettua että tislattua kuminaöljyä.

Tässä tutkimuksessa kaikki koekappaleet olivat höylättyä männyn pintapuuta, mikä on yleisin puulaji tutkittaessa aineiden tehokkuutta puutavaran suojauksessa. Sinistymän- ja homeenestokokeissa sekä maalin homeenestokokeissa laboratoriossa, koekappaleiden koko oli 5x25x50 mm. Lahoamisen estokokeessa kappaleiden koko oli 5x15x15 mm. Kenttäkokeen lautojen koko oli standardissa EN 927-3 vaadittu, 20x100x375 mm.

Käytetyt homesienet olivat: Aspergillus versicolor, Cladosporium sphaerospermum ja puutavarasta eristetty Penicillium sp. Käytetyt sinistäjäsienet olivat: Aureobasidium pullulans, Ceratocystis pilifera ja Sclerophoma entoxylina. Lahottajasienet olivat standardin EN 113 sienikantoja: Coniophora puteana, Poria placenta ja Coriolus versicolor.

Koekappaleiden käsittelyt kuminaöljyillä sinistymän- ja homeenestokokeisiin tehtiin kolmella tavalla: liotus öljyssä 1 vrk, upotus öljyyn $20 \mathrm{~s}$ tai sively pensselillä 2 kertaa välillä kuivaten. Käsittelyjen jälkeen kappaleet saivat kuivua huonetilassa 6 viikkoa ennen sienialtistuksia. Lahotuskokeeseen koekappaleet kyllästettiin tyhjökyllästyslaitteella $10,20,50$ tai 100 prosenttisilla öljyillä erilaisten öljymäärien saamiseksi puuhun. Laimennus tehtiin ksyleenillä, joka ei vaikuta lahotustuloksiin. Vertailuna käytettiin pellavaöljyä samoin laimennettuna. Koekappaleet saivat kuivua kyllästyksen jälkeen 6 viikkoa ennen sienialtistusta.

Kuminaöljyjen vaikutusta maalien homehtumiseen tutkittiin laboratoriossa kahdella vesiohenteisella mallimaalilla, jotka eivät sisältäneet homeenestoaineita. Kokeita varten puukappaleet siveltiin ensin kuminaöljyillä kerran tai kahdesti ja maalattiin sitten kerran akrylaatti- tai alkydi/akrylaattimaalilla. Vaihtoehtoisesti kappaleet maalattiin kerran mallimaaleilla, joihin oli lisätty $10 \%$ kuminaöljyä. Homesienialtistus aloitettiin maalien kuivuttua.

\section{Sienitestit laboratoriossa}

Puun sinistymän- ja homeenestokokeet sekä maalattujen kappaleiden homeenestokokeet tehtiin samalla periaatteella. Koekappaleet ruiskutettiin sinistäjä- tai homesienistä valmistetulla itiösuspensiolla ja koekappaleet laitettiin testikammioihin, vakaatasoon ritilän päälle. Tarpeellisen kosteuden varmistamiseksi kammioiden pohjalla oli vettä. Eri öljyillä käsitellyt kappaleet tulivat eri kammioihin. Kammioita säilytettiin pimeässä huonetilassa. Sienten kasvu koekappaleiden yläpinnalla arvosteltiin viikon välein visuaalisesti seuraavan asteikon mukaan: $0=$ ei kasvua, $1=$ merkkejä kasvusta, $2=1-10 \%$ pinnasta sienikasvuston peitossa, $3=10-30 \%$ pinnasta sienikasvuston peitossa, $4=30-70 \%$ pinnasta sienikasvuston peitossa ja 5 = yli $70 \%$ pinnasta sienikasvuston peitossa.

Lahotuskoetta varten kyllästetyt, kuivuneet ja punnitut koekappaleet steriloitiin säteilyttämällä. Koekappaleet laitettiin sitten Petri-maljoihin, joissa mallasagaralustalla kasvoi sienipuhdasviljelmä. Sienialtistus kesti 7 viikkoa kasvatushuoneessa, jossa ilman suhteellinen kosteus oli $70 \%$ ja lämpötila 22 ${ }^{\circ} \mathrm{C}$. Kokeen lopussa koekappaleista poistettiin pinnalta sienirihmasto, kappaleet kuivattiin ja punnittiin. Kappaleista laskettiin painohäviöt prosentteina alkupainosta. 


\section{Kenttäkoe}

Ennen maalauksia koelautojen päätypinnat suojattiin kaupallisella alkydiöljymaalilla. Laudat pohjakäsiteltiin kuminaöljyillä sivelemällä kerran. Maaleina käytettiin kaupallista alkydiöljymaalia ja laboratoriokokeessa käytettyä vesiohenteista alkydi/akrylaattimaalia. Maalaus tehtiin kaksi kertaa joko edellä mainituilla maaleilla tai ensimmäinen kerta maalilla, johon oli lisätty $10 \%$ kuminaöljyä. Maalien kuivuttua koekappaleet asetettiin telineeseen 45 asteen kulmaan, maalattu pinta ylöspäin ja kohti etelää VTT:n koekentälle Otaniemeen kesäkuun lopussa 2000. Maalipintojen kuntoarviot tehtiin 3 kk kuluttua ja 15 kk kuluttua. Pinnoista arvosteltiin maalin halkeilu, hilseily ja kupliminen sekä sienten kasvu maalipinnoilla.

\section{Tulokset ja tulosten tarkastelu}

\section{Puun homehtumisen ja sinistymisen esto}

Kuminaöljyt eivät estäneet puun homehtumista käsittelyn jälkeen kuusi viikkoa kuivuneissa kappaleissa. Jo kolmen viikon kuluttua käsitellyt kappaleet olivat homehtuneet arvosteluasteikon korkeimmalle tasolle 5, kuten käsittelemättömät vertailukappaleet.

Sinistymisen estossa kuminaöljyt olivat hiukan tehokkaampia kuin homehtumisen estossa. Puristettu kuminaöljy oli tislattua tehokkaampi ja liotuskäsittely paras, sillä tällöin imeytynyt öljymäärä oli suurin. 7 viikon sienialtistuksen jälkeen vain liotus puristetussa kuminaöljyssä antoi vähän suojaa sinistymistä vastaan (Taulukko 1). Pitkä kuivausaika heikensi haihtumisen vuoksi kuminaöljyjen tehokkuutta.

Taulukko 1. Puun sinistyminen kuminaöljyillä käsitellyissä koekappaleissa. Tulokset ovat neljän kappaleen keskiarvoja.

\begin{tabular}{lllllll}
\hline \multirow{2}{*}{ Öljy } & & \multicolumn{2}{l}{ Sinistyminen } & & & \\
Kislattu kuminaöljy & Liotus 1 vrk & 0 & 2,5 & 3,8 & 4,3 & 4,8 \\
& Kasto 20 s & 0 & 2,5 & 3,8 & 4,3 & 4,5 \\
& 2 sivelyä & 0 & 2,8 & 3,8 & 4,0 & 4,5 \\
Puristettu kuminaöljy & Liotus 1 vrk & 0 & 0,8 & 1,5 & 2,3 & 3,3 \\
& Kasto 20 s & 0 & 0,3 & 4,0 & 4,5 & 4,8 \\
& 2 sivelyä & 0 & 1,8 & 2,5 & 4,0 & 4,5 \\
Ei öljyä & Käsittelemätön & 0,5 & 4,0 & 4,5 & 4,5 & 4,5 \\
\hline
\end{tabular}

\section{Puun lahoamisen esto}

Lahotuskokeen alkuvaiheessa Poria placenta näytti karttavan käsiteltyjä kappaleita. Kuitenkin kokeen lopussa tämä sieni lahotti eniten kaikilla öljyillä käsiteltyjä kappaleita (Taulukko 2). Puristettu kuminaöljy oli tehokkain lahoamisen estossa. Tislatun kuminaöljyn tehokkuus oli pienin, mikä johtuu siitä, että tehokkaat haihtuvat yhdisteet ovat poistuneet puusta 6 viikon pituisessa kuivausvaiheessa. Puristetussa kuminaöljyssä tulee vaikuttavaksi tekijäksi ehkä myös puun kostumisen esto. Pellavaöljyn tehokkuus perustuu tähän vaikutukseen. Lahoamisen estoon tarvittavat kuminaöljymäärät ovat niin suuria, $250-500 \mathrm{~kg} / \mathrm{m}^{3}$, ettei niiden käyttö olisi taloudellisesti kannattavaa. 
Taulukko 2. Koekappaleiden keskimääräiset painohäviöt 7 viikon lahotuskokeessa mallasagaralustalla. Tulokset ovat neljän kappaleen keskiarvoja.

\begin{tabular}{lccccc}
\hline Käsittely & & $\begin{array}{c}\text { Imeytymä } \\
\mathbf{k g} / \mathbf{m}^{\mathbf{3}}\end{array}$ & $\begin{array}{c}\text { Painohäviö \% } \\
\text { Coniophora } \\
\text { puteana }\end{array}$ & $\begin{array}{c}\text { Poria } \\
\text { placenta }\end{array}$ & $\begin{array}{c}\text { Coriolus } \\
\text { versicolor }\end{array}$ \\
\hline Tislattu kuminaöljyy & $10 \%$ & 48 & 31,9 & 36,4 & 11,1 \\
& $20 \%$ & 98 & 18,5 & 33,1 & 12,4 \\
Puristettu kuminaöljy & $50 \%$ & 244 & 9,7 & 30,7 & 9,1 \\
& $100 \%$ & 536 & 7,9 & 9,3 & 3,8 \\
& $20 \%$ & 48 & 9,7 & 36,9 & 12,1 \\
Pellavaöljy & $50 \%$ & 254 & 0,8 & 33,0 & 11,0 \\
& $100 \%$ & 511 & 0,6 & 13,2 & 4,0 \\
& $10 \%$ & 51 & 19,7 & 1,4 & 1,6 \\
Käsittelemätön & $20 \%$ & 257 & 11,2 & 38,6 & 7,0 \\
& $50 \%$ & 508 & 3,5 & 21,9 & 7,8 \\
& $100 \%$ & - & 25,0 & 6,1 & 4,3 \\
& & & & 40,8 & 11,3 \\
\hline
\end{tabular}

\section{Maalin homehtumisen esto}

Laboratoriokokeessa tislattu kuminaöljy maalin pohjusteena esti viiden viikon ajan mallimaalien homehtumisen. Puristetun kuminaöljyn vaikutus oli lyhytaikaisempi. $10 \%$ tislattua kuminaöljyä maaliin sekoitettuna oli tehokas alkydi/akrylaattimaalissa, mutta tämä määrä ei estänyt akrylaattimaalin homehtumista (Taulukko 3).

Kuminaöljyistä haihtuvat yhdisteet estivät kokeen alussa myös samoissa kammioissa olevien käsittelemättömien puukappaleiden homehtumisen. Haihtumisesta johtuen kuminaöljyn tehokkuus maalatun pinnan homehtumisen estossa ei ole pitkäaikainen.

Taulukko 3. Maalipintojen keskimääräinen homehtuminen 10 viikon aikana. Kappaleet olivat neljässä kammiossa, joissa kaikissa oli vertailuna käsittelemätön männyn pintapuu.

\begin{tabular}{llllllll}
\hline Käsittely & $\begin{array}{l}\text { 1 } \\
\text { vko }\end{array}$ & $\begin{array}{l}\mathbf{2} \\
\text { vko }\end{array}$ & $\begin{array}{l}\mathbf{3} \\
\text { vko }\end{array}$ & $\begin{array}{l}\mathbf{4} \\
\text { vko }\end{array}$ & $\begin{array}{l}\mathbf{5} \\
\text { vko }\end{array}$ & $\begin{array}{l}\mathbf{7} \\
\text { vko }\end{array}$ & $\begin{array}{l}\mathbf{1 0} \\
\text { vko }\end{array}$ \\
\hline Maali 1 (akrylaatti) & 2,8 & 4,3 & 5 & 5 & 5 & 5 & 5 \\
Maali 2 (alkydi/akrylaatti) & 1,0 & 3,5 & 5 & 5 & 5 & 5 & 5 \\
Puu & 4,3 & 5 & 5 & 5 & 5 & 5 & 5 \\
& & & & & & & \\
Tisl.kuminaöljy 1 sively + maali 1 & 0 & 0 & 0 & 0,3 & 0,3 & 2,5 & 4,5 \\
Tisl.kuminaöljy 1 sively + maali 2 & 0 & 0 & 0 & 0,3 & 0,5 & 3,3 & 4,5 \\
Tisl.kuminaöljy 2 sivelyä + maali 1 & 0 & 0 & 0 & 0 & 0 & 1,3 & 3,3 \\
Tisl.kuminaöljy 2 sivelyä + maali 2 & 0 & 0 & 0 & 0,3 & 0,5 & 3,5 & 4,5 \\
Puu & 0 & 0 & 0,8 & 1,5 & 2,5 & 4,8 & 5 \\
& & & & & & & \\
Purist.kuminaöljy 1 sively + maali 1 & 0 & 2,8 & 5 & 5 & 5 & 5 & 5 \\
Purist.kuminaöljy 1 sively + maali 2 & 0 & 0 & 1,8 & 2,5 & 3,5 & 4,5 & 5 \\
Purist.kuminaöljy 2 sivelyä + maali 1 & 0 & 0 & 0 & 2,5 & 4,0 & 5 & 5 \\
Purist.kuminaöljy 2 sivelyä + maali 2 & 0 & 0 & 0 & 2,5 & 4,0 & 4,8 & 5 \\
Puu & 0,3 & 2,5 & 4,0 & 4,8 & 5 & 5 & 5 \\
& & & & & & & \\
Tisl.kuminaöljyä 10 \% maalissa 1 & 0 & 0,3 & 2,3 & 3,5 & 4,0 & 4,5 & 4,8 \\
Tisl.kuminaöljyä 10 \% maalissa 2 & 0 & 0 & 0 & 1,3 & 2,5 & 2,8 & 4,8 \\
Puu & 0 & 0 & 3,5 & 5 & 5 & 5 & 5 \\
\hline
\end{tabular}


Yli vuoden pituisen kenttävanhennuksen jälkeen tislattu kuminaöljy maalin pohjusteena esti vielä selvästi maalipinnan homehtumista. Paras tehokkuus oli tiiviin kaupallisen alkydiöljymaalin alla. Tällöin öljyn haihtuminen oli vähäisempää kuin käytetyn mallimaalin alta. Puristetun kuminaöljyn homehtumisen estovaikutus oli pienempi. Kenttäkokeessa todettiin myös, että kuminaöljyt eivät vaikuttaneet haitallisesti maalien ominaisuuksiin, hilseily ja kupliminen eivät lisääntyneet.

\section{Johtopäätökset}

Kuminaöljyllä oli paras tehokkuus maalien homehtumisen estossa varsinkin silloin, kun öljyä käytettiin maalin pohjusteena ja maali esti öljyn haihtumisen. Kuminaöljy ei vaikuttanut huonontavasti maalin ominaisuuksiin. Suuret kuminaöljypitoisuudet puussa estivät lahoamista, mutta puuhun tarvitaan niin suuret kuminaöljypitoisuudet, että käytännössä se ei ole kannattavaa. Kuminaöljyt estivät jonkin verran puun sinistymistä, mutta homehtumiseen niillä ei ollut vaikutusta. Kuminaöljyllä voidaan saada sen yhdisteiden haihtuvuuden vuoksi puutavaralle vain lyhytaikainen suoja sinistäjäsieniä vastaan.

\section{Kirjallisuus}

1 Hartmans, K.J., Diepenhorst, p., Bakker, W.\& Gorris, L.G.M. 1995. The use of carvone in agriculture: sprout supression of potatoes and antifungal activity against potato tuber and other plant diseases. Industrial Crops and Products 4: 3-13.

2 Oosterhaven, K., Poolman, B. \&Smid, E.J. 1995. S-Carvone as a natural potato sprout inhibiting, fungistatic and bacterstatic compound. Industrial Crops and Products 4: 23-31.

3 Väisälä, L. 1974. Effect of terpene compounds on the growth of wood-decomposing fungi. Ann. Bot. Fennici 11:275-278.

4 Väisälä, L. 1978. Effects of terpene compounds on the growth and peroxidase activity of Phellinus pini. Ann. Bot. Fennici 15:131-137. 